\title{
NECROPOLÍTICA: RACISMO E POLÍTICAS DE MORTE NO BRASIL CONTEMPORÂNEO
}

\section{NECROPOLITICS: RACISM AND DEATH POLITICS IN CONTEMPORARY BRAZIL}

\author{
Maiquel Ângelo Dezordi Wermuth ${ }^{1}$ \\ Laura Mallmann Marcht ${ }^{2}$ \\ Letícia de Mello $^{3}$
}

\section{Resumo}

O artigo tem por objetivo apresentar a categoria filosófica da necropolítica, a partir da obra do camaronês Achille Mbembe, aqui utilizada como background teórico para contextualizar a morte em massa de pessoas majoritariamente pobres e negras no Brasil contemporâneo. A problemática que orienta a pesquisa pode ser assim sintetizada: em que medida a necropolítica pode ser compreendida como categoria filosófica para compreensão da morte massificada de vidas "descartáveis" - evidenciada pelo alto índice de violência policial contra pessoas pobres e negras no Brasil atual - e que remonta à violência constitutiva da sociedade brasileira desde o período colonial, marcado pela escravidão? Tem-se como hipótese que pessoas pobres e negras têm sido o alvo do Estado, de forma majoritária, desde o Brasil Colônia - contexto em que se fixa uma violência estrutural contra esses sujeitos - e que a política de morte elucidada por Achille Mbembe permite explicar as raízes dessa violência e seletividade. Por meio da técnica da pesquisa bibliográfica e do método genealógico de matriz foucaultiana, o texto, que se estrutura em duas partes, discorre inicialmente sobre a violência contra pobres e negros desde o Brasil Colônia até o contexto contemporâneo; na segunda parte, apresenta-se a necropolítica,

\footnotetext{
${ }^{1}$ Doutor em Direito Público (UNISINOS). Professor dos Cursos de Direito da UNIJUÍ e da UNISINOS Coordenador do Programa de Pós-Graduação Stricto Sensu - Mestrado e Doutorado em Direitos Humanos - da UNIJUÍ. Líder do Grupo de Pesquisa Biopolítica \& Direitos Humanos (CNPq) Pesquisador Gaúcho - Edital FAPERGS no 05/2019. Universidade Regional do Noroeste do Estado do Rio Grande do Sul - UNIJUÍ, Rio Grande do Sul; Universidade do Vale do Rio dos Sinos - UNISINOS, Rio Grande do Sul. ORCID iD: $\quad$ http://orcid.org/0000-0002-7365-5601. Lattes: http://lattes.cnpq.br/0354947255136468 E-mail: madwermuth@gmail.com

${ }^{2}$ Mestranda em Direitos Humanos pela Universidade Regional do Noroeste do Estado do Rio Grande do Sul - UNIJUÍ; Bolsista UNIJUÍ. Universidade Regional do Noroeste do Estado do Rio Grande do Sul - UNIJUÍ, Rio Grande do Sul - Brasil. ORCID iD: http://orcid.org/0000-0002-0780-0452 Lattes:

http://lattes.cnpq.br/7282873952951659 E-mail: madwermuth@gmail.com

${ }^{3}$ Acadêmica do Curso de Graduação em Direito da Universidade do Vale do Rio dos Sinos - UNISINOS, Rio Grande do Sul. Universidade do Vale do Rio dos Sinos - UNISINOS, Rio Grande do Sul - Brasil. ORCID iD: $h$ ttps://orcid.org/0000-0003-0066-1098 Lattes: http://lattes.cnpq.br/1769287901210599 E-mail: madwermuth@gmail.com
} 
categoria central do texto, relacionando-a com a violência e as sobreditas mortes e especificidades das vítimas.

Palavras-chave: Escravidão; Necropolítica; Seletividade; Violência.

\section{Abstract}

The article aims to present the philosophical category of necropolitics, based on the work of cameroonian Achille Mbembe, here used as a theoretical background to contextualize the mass death of mostly poor and black people in contemporary Brazil. The problem that guides the research can be summarized as follows: to what extent the necropolitics can be understood as a philosophical category for understanding the mass death of "disposable" lives - evidenced by the high rate of police violence against poor and black people in Brazil today - and dating back to the constitutive violence of Brazilian society since of the colonial period, marked by slavery? It has been hypothesized that poor and black people have been the target of the State, in a majority form, since Colonial Brazil - a context in which structural violence against these subjects is fixed - and that the death policy elucidated by Achille Mbembe allows to explain the roots of this violence and selectivity. Using the technique of bibliographic research and the genealogical method of Foucaultian matrix, the text, which is structured in two parts, initially discusses violence against the poor and black people from colonial Brazil to the contemporary context; in the second part is presented the necropolitics, the central category of the text, relating it to violence and the above-mentioned deaths and specificities of the victims.

Keywords: Slavery; Necropolitics; Selectivity; Violence.

\section{CONSIDERAÇÕES INICIAIS}

Caso 1 - 14 de março de 2018: a vereadora carioca Marielle Franco foi assassinada, no centro do Rio de Janeiro, quando voltava de um evento com mulheres negras defensoras de direitos humanos. No momento do crime, ela estava em um carro acompanhada de uma assessora - que foi ferida e sobreviveu - e do motorista - que foi atingido pelos disparos e também morreu no local. A vereadora recebeu quatro tiros na cabeça, de um total de nove disparos dirigidos contra a janela traseira do carro, o que, segundo as declarações públicas das 
autoridades policiais, fundamentaria a hipótese de que se tratou de um crime premeditado. Eleita com mais de 46.000 votos, em 2016, Marielle foi a quinta parlamentar mais votada no Rio naquela eleição. Sua atuação como vereadora foi marcada pela defesa dos direitos da população negra das periferias cariocas (COMISSÃO INTERAMERICANA DE DIREITOS HUMANOS, 2018).

Em face à intervenção federal no Rio de Janeiro ${ }^{4}$, Marielle criticou veementemente a utilização constante da violência pelos policiais, o que, segundo ela, se equiparava à violência que - retoricamente - se buscava combater: a do tráfico. Em uma de suas redes sociais, a vereadora salientou que "do tráfico não se cobra a lei e o respeito", postura essa que se deve cobrar do Estado (ODILLA, 2018). Até o momento, o caso Marielle não foi solucionado pelas autoridades públicas brasileiras.

Caso 2 - 7 de abril de 2019: Evaldo Rosa dos Santos foi morto durante uma operação conduzida por doze militares em Guadalupe, na Zona Norte do Rio de Janeiro. Oitenta disparos de fuzil alvejaram o veículo que ele conduzia. No veículo, além de Evaldo, estavam seu sogro que também foi ferido -, sua esposa, o filho do casal e uma amiga da família - estes últimos não vitimados. Um catador de materiais recicláveis, Luciano Macedo, estava nas proximidades e resolveu ajudar a família, sendo também morto na operação. O Ministério Público Militar (MPM) contabilizou duzentos e cinquenta e sete disparos de fuzil pelos militares durante a abordagem do veículo de Evaldo (JUCÁ, 2020).

Como não foram encontradas quaisquer armas com as vítimas, a alegação dos militares sobre a ação é de que estariam respondendo a uma "injusta agressão", tendo confundido o carro da família - que estava se deslocando para um chá de bebê (!!!) - com outro veículo que estava sendo procurado (JANSEN, 2020). De acordo com os depoimentos, a polícia não solicitou a Evaldo que parasse o carro. Ainda, os moradores do local gritaram para avisar aos militares que as vítimas eram habitantes do local, sem êxito, pois eles continuaram a atirar. A deputada e presidente da Comissão de Direitos Humanos da Assembleia Legislativa do Rio de Janeiro, Renata Souza (PSOL), afirmou que não seria o primeiro incidente na região, o que evidencia uma clara "política do abate" por parte da polícia militar (JANSEN, 2020). Os militares estão

\footnotetext{
${ }^{4}$ Em 16 de fevereiro de 2018, por meio do Decreto no 9.288/2018, a presidência da República, sob justificativa de "pôr termo ao grave comprometimento da ordem pública" - nos termos do preâmbulo do Decreto - determinou a intervenção federal no Estado do Rio de Janeiro. A edição do Decreto - com vigência prevista até 31 de dezembro de 2018 - representou uma medida inédita durante o período de redemocratização do país, inaugurado pela Constituição Federal de 1988.
} 
respondendo em liberdade, em sua maioria, pelos crimes de dois homicídios qualificados, tentativa de homicídio qualificada e omissão de socorro (BARBON, 2020).

Caso 3 - 21 de setembro de 2019: Ágatha Felix, de 8 anos de idade, foi morta em uma operação policial no complexo de favelas do Alemão, no Rio de Janeiro, quando retornava para casa, na companhia de sua mãe, ambas no interior de uma Kombi. As versões apresentadas ao fatídico caso são antagônicas: de um lado, a família afirmou que, no momento em que a menina foi alvejada, não havia confronto entre militares e traficantes, sendo que as testemunhas do caso foram uníssonas em afirmar que o tiro que matou Ághata teria partido da arma de um policial. De outra banda, a versão apresentada oficialmente pela corporação que realizava o patrulhamento quando do incidente afirmou que, na ocasião, o tiro incidental proveio de um confronto entre policiais e tripulantes de uma moto que era conduzida por bandidos que reagiram à presença policial.

A versão dos policiais foi refutada. A conclusão do inquérito investigativo apontou que a menina foi morta em consequência de um projétil oriundo da arma de um policial, o qual ricocheteou ao alvejar um poste, após se perder do alvo - tripulantes da moto -, e que atravessou a estrutura metálica do veículo em que Ágatha se encontrava, acertando-a fatalmente. Outrossim, concluiu-se que a moto, em verdade, era tripulada por dois cidadãos que não estavam envolvidos com o tráfico. O policial responsável pelo disparo, "equivocadamente", confundiu um encanamento de metal que o caroneiro da moto transportava consigo com uma arma e, por conseguinte, abriu fogo contra a motocicleta (BETIM, 2019).

Os três casos apresentados envolvem violência contra corpos negros. Todos os episódios se relacionam à atuação estatal no campo da segurança pública - seja por ação, seja por omissão. A totalidade dos acontecimentos chama a atenção à magnitude do fato morte nas periferias brasileiras.

A partir dos casos Marielle Franco, Evaldo Rosa dos Santos e Ágatha Vitória Sales Félix, esta pesquisa tem por objetivo apresentar a categoria filosófica da necropolítica, a partir da obra do camaronês Achille Mbembe, aqui utilizada como pano de fundo para contextualizar a morte em massa de pessoas majoritariamente pobres e negras no Brasil contemporâneo. Nesse cenário é que se insere a problemática que orienta a pesquisa: em que medida a necropolítica pode ser compreendida como categoria filosófica para compreensão da morte massificada de vidas "descartáveis" - evidenciada pelo alto índice de violência policial contra pessoas pobres e 
negras no Brasil atual - e que remonta à violência constitutiva da sociedade brasileira desde o período colonial, marcado pela escravidão?

Tem-se como hipótese que pessoas pobres e negras têm sido o alvo do Estado, de forma majoritária, desde o Brasil Colônia - contexto em que se fixa uma violência estrutural contra esses sujeitos - e que a política de morte elucidada por Achille Mbembe permite explicar as raízes dessa violência e seletividade.

A pesquisa é perspectivada por meio da técnica da pesquisa bibliográfica e do método genealógico foucaultiano, o qual trabalha "a partir da diversidade e da dispersão, do acaso dos princípios e dos acidentes", sendo que de forma alguma a genealogia, nestes termos, "deseja voltar no tempo para restabelecer a continuidade da história, mas procura, em contraposição, restituir os acontecimentos em sua singularidade." (REVEL, 2011, p. 69). Nesse sentido, o presente texto aborda questões da contemporaneidade sem perder de vistas fatos do passado histórico do país, o que justifica a escolha metodológica, na medida em que referido método genealógico - representa justamente "uma tentativa de desassujeitar os saberes históricos", de modo a "torná-los capazes de se opor e de lutar contra a 'ordem do discurso'." Desse modo, é possível afirmar que a "genealogia não busca somente no passado a marca de acontecimentos singulares, mas que ela se questiona a respeito da possibilidade dos acontecimentos do dia de hoje." (REVEL, 2011, p. 70).

Considera-se, também, na construção do texto, a questão do "lugar de fala" (RIBEIRO, 2017). Com efeito, o presente artigo é escrito por pessoas brancas que percebem as consequências do racismo estrutural para a população negra, mas que não são afetadas diretamente por ele, razão pela qual se utilizam do privilégio acadêmico e social que a branquitude viabiliza para tratar dessa temática, apontando a crítica e promovendo a visibilidade.

O megaterror do século XX, não é reflexo da teoria da "banalidade do mal" descrita por Hannah Arendt (1999) em Eichmann em Jerusalém, mas se pode temer que a aquiescência da tortura tenha se arraigado de forma tão íntima na sociedade, que talvez essas medidas não precisem mais ser tomadas no século XXI (HOBSBAWM, 2007), ante às mudanças dos mecanismos de controle na atualidade. É devido a essas alterações que os mecanismos aperfeiçoaram seus respectivos objetivos: primeiramente controlam os sujeitos docilizados, e após, descartam aqueles que são indesejáveis. É aqui que a necropolítica se insere.

O texto se estrutura em duas partes. Na primeira, discorre-se sobre a violência policial contra pobres e negros desde o Brasil Colônia até o contexto contemporâneo. Nessa seção, 
serão apresentados dados e estatísticas que permitirão analisar o perfil das vidas ditas "descartáveis". Desse modo, na segunda parte será possível apresentar a necropolítica, categoria central do texto, relacionando-a com a violência e as sobreditas mortes e especificidades das vítimas.

\title{
2 A VIOLÊNCIA POLICIAL CONTRA PESSOAS NEGRAS E POBRES NO BRASIL: da Colônia à contemporaneidade
}

"Todos nós herdamos no sangue lusitano uma boa dose de lirismo... (além da sífilis, é claro) Mesmo quando as minhas mãos estão ocupadas em torturar, esganar, trucidar Meu coração fecha os olhos e sinceramente chora..." (Chico Buarque de Holanda. Fado tropical)

Escrever sobre a história do povo negro no Brasil - até mesmo por força das questões que envolvem o "lugar de fala", como salientado na introdução - não é tarefa branda. A trajetória dos negros em solo brasileiro foi forjada, desde os primórdios, pela violência física e psicológica, pela submissão e pela desvalorização do ser enquanto humano - tudo isso mascarado pelo mito da "democracia racial", difundido, principalmente, a partir da obra de Gilberto Freyre (2002, p. 301):

\begin{abstract}
Na ternura, na mímica excessiva, no catolicismo em que se deliciam nossos sentidos, na música, no andar, na fala, no canto de ninar menino pequeno, em tudo que é expressão sincera de vida, trazemos quase todos a influência negra. Da escrava ou sinhama que nos embalou. Que nos deu de mamar. Que nos deu de comer, ela própria amolegando na mão o bolão de comida. Da negra velha que nos contou as primeiras histórias de bicho e de mal-assombrado. Da mulata que nos tirou o primeiro bicho de pé de uma coceira tão boa. Da que nos iniciou no amor físico e nos transmitiu, ao ranger da cama de vento, a sensação completa de homem. Do muleque que foi o nosso primeiro companheiro de brinquedo.
\end{abstract}

Ocorre que essa percepção de "democracia racial" - como o próprio adjetivo "mito" denuncia - longe está da realidade. Em Florestan Fernandes (1965) encontramos a denúncia: o legado do escravismo não foi a mestiçagem; foi, antes, a consolidação de uma desigualdade social que faz sentir seus efeitos até hoje.

Com efeito, a ideia de "fusão de raças" e "democracia racial", de acordo com a análise de Schwarcz (2019, p. 20-21), funcionou no brasil como "mito fundante", ou seja, uma 
formulação cujo objetivo era "produzir nos cidadãos o sentimento de pertencer a uma comunidade única, a qual permaneceria para sempre inalterada." A construção de "mitos fundantes", ou seja, de uma "história oficial" cumpre, na visão da referida autora, com um papel estratégico nas políticas do Estado, na medida em que permitem engrandecer certos eventos e suavizar "problemas que a nação vivenciou no passado mas prefere esquecer, e cujas raízes ainda encontram repercussão no tempo presente."

No caso brasileiro, o mito fundante da democracia racial serviu como retórica para ocultar o fato de que, "em lugar do idílio, escravizados conheceram por aqui toda forma de violência" (SCHWARCZ, 2019, p. 23). Além disso, o referido mito ajuda a mitigar o fato de que grassou, no Brasil, entre os séculos XVI e XIX, "uma grande bastardia jurídica", alicerçada na "total falta de direitos de alguns ante a imensa concentração de poderes nas mãos de outros" (SCHWARCZ, 2019, p. 27).

De fato, a escravidão nos moldou enquanto sociedade. Para além de um sistema econômico, ela foi responsável por formatar condutas, arquitetar espaços urbanos alicerçados na lógica da diferença/exclusão e definir, de modo muito contundente, desigualdades sociais. Além disso, a escravidão "fez de raça e cor marcadores de diferença fundamentais, ordenou etiquetas de mando e obediência, e criou uma sociedade condicionada pelo paternalismo e por uma hierarquia muito estrita." (SCHWARCZ, 2019, p. 27-28).

Nos famosos "pelourinhos" das principais capitais do país - foram praticadas indizíveis atrocidades contra a população escrava (WERMUTH, 2018). Os senhores de escravos foram responsáveis, no Brasil, pela invenção "de verdadeiras arqueologias de castigos, que iam chibatada em praça pública até a palmatória." (SCHWARCZ, 2019, p. 29). Essas cenas, de tão frequentes, acabaram incorporadas ao "cotidiano" das cidades, sendo retratadas até mesmo nas aquarelas de Jean Baptiste Debret ${ }^{6}$. Nilo Batista (2002, p. 149), ao abordar os castigos impostos aos cativos, salienta a existência, no período escravocrata, de uma espécie de "direito penal privado" no âmbito do qual eram praticadas "as maiores atrocidades no Brasil colonial". A título de exemplo, o penalista relata:

\footnotetext{
${ }^{5}$ O pelourinho "era uma coluna de pedra ou madeira, picota, a prumo, posta em alguma praça principal da vila ou cidade, à qual se atava pela cintura o preso que se expunha à vergonha, ou era açoutado; tinha argola, onde se podia enforcar e dar tratos de polé." (GARCIA, 1956, p. 97).

6 Imagem disponível em: <http://escolaeducacao.com.br/brasil-colonial-de-jean-baptiste-debret/>. Acesso em: 26 mar. 2020.
} 
em 1591, Fernão Cabral de Taíde prestava declarações ao visitador do Santo Ofício na Bahia, sobre um culto popular no sertão; a certa altura, relata que 'uma noite, estando uma negra sua inchada de comer terra e quase para morrer (...) disse a dois negros seus que a botassem na fornalha'. O visitador prossegue a inquirição sobre a seita, e percebe-se que seu interesse está todo concentrado nas supostas práticas de idolatria; a escrava em pleno 'banzo' queimada viva não era pecado que merecesse atenção.

Em um regime de escravidão, o escravo é mantido vivo em um “'estado de injúria', em um mundo espectral de horrores, crueldade e profanidade intensos." Nesse contexto, "o curso violento da vida de escravo se manifesta pela disposição de seu capataz em se comportar de forma cruel e descontrolada ou no espetáculo de sofrimento imposto ao corpo do escravo." Em um cenário tal, a violência "torna-se um componente da etiqueta, como dar chicotadas ou tirar a vida do escravo: um capricho ou um ato de pura destruição visando incutir o terror", de modo que "a vida do escravo, em muitos aspectos, é uma forma de morte-em-vida." (MBEMBE, 2018a, p. 28-29).

Com efeito, em um sistema escravista, "a humanidade de uma pessoa é dissolvida até o ponto em que se torna possível dizer que a vida do escravo é propriedade do seu senhor." E, na medida em que a vida do escravo se transmuta em "coisa" que é passível de ser possuída por outra pessoa, "sua existência é a figura perfeita de uma sombra personificada." (MBEMBE, 2018a, p. 30).

Obviamente que uma sociedade forjada com tamanha violência colhe os frutos da profunda desigualdade estrutural que the subjaz. A escravidão criou no Brasil "uma singularidade excludente e perversa" e uma "sociabilidade que tendeu a se perpetuar no tempo, precisamente porque nunca foi efetivamente compreendida nem criticada" (SOUZA, 2017, p. 9) - eis que transmutada em "mito". Nesse sentido, torna-se possível afirmar que "nenhuma outra questão é mais importante e nada singulariza mais o Brasil" do que a escravidão, que se transforma, portanto, na "grande questão social, econômica e política" do país, cristalizada na "existência continuada dessa ralé de novos escravos." (SOUZA, 2017, p. 105).

Tais constatações demonstram que as questões raciais, no Brasil, não se constituem enquanto um movimento transitório: elas nos acompanham desde nossa formação. Logo, o preconceito racial contra a população afrodescendente não deve jamais ser visto como um episódio isolado, senão como um verdadeiro atentado contra a dignidade deste povo que sofre há mais de quinhentos anos em solo brasileiro - aquela classe que Souza (2017) denomina de 
"ralé de novos escravos" é, a todo momento, estigmatizada - exatamente como ocorre com as castas inferiores do hinduísmo:

Como ela [ralé de novos escravos] é estigmatizada e ninguém quer sequer chegar perto dela [...], a escola e a saúde, por exemplo, que se destinam a ela são aviltadas. A insegurança pública crônica, já que a ausência de oportunidades reais manda uma parte dessa classe para o crime - no homem a figura típica é o bandido, enquanto para a mulher é a prostituta -, decorre desse abandono. Afinal, existem aqueles entre os excluídos que não querem se identificar com o 'pobre otário' que trabalha pormigalhas para ser 'tapete de bacana'. Tudo, enfim, que identificamos com os grandes problemas brasileiros - como, além dos elencados acima, a 'baixa produtividade' do trabalhador brasileiro - tem relação com esse abandono [e violência estrutural, acrescente-se] secular (SOUZA, 2017, p. 105).

Em que pese os discursos abolicionistas - gize-se: oriundos, em sua maior parte, de uma classe que sustentava seus privilégios na base do açoite (NEDER; CERQUEIRA FILHO, 2006) - o negarem peremptoriamente, a abolição sempre foi pensada em prol do interesse das classes hegemônicas, pois, libertos, jamais aos negros foram destinadas políticas de inserção social ou de regresso aos países de origem. A Lei de 13 de maio de 1888 representou, na visão de Schwarcz (2019, p. 30), "uma solução de compromisso", na medida em que "não ressarciu os senhores, que esperavam receber indenização do Estado por suas 'perdas'", mas da mesma forma "não previu nenhuma forma de integração das populações recém-libertas, inaugurando um período chamado de pós-emancipação, que teve data para começar mas não para terminar." Negligenciados, os espólios da escravidão instalaram-se em locais precários, sem acesso à educação ou aos bens culturais - o que ainda é muito atual no cenário urbano brasileiro, marcado por cinturões de pobreza incomensuráveis, nos quais as condições de vida ainda são, para milhares de pessoas, hobbesianas.

Após a libertação dos escravos, as demandas de ordem social dessa população não foram acompanhadas de uma proposta estatal. Nesta senda, estavam lançadas as condições que acabariam por relegar os libertos a uma subposição social: uma vez livres e sem assistência do Estado, tais condições foram decisivas para posicioná-los em patamares de subalternidade e marginalização. Eis, portanto, as origens das mazelas que culminaram na atual desestrutura social que tem como pano de fundo o preconceito racial como legitimador da violência contra negros, sobretudo em se tratando de negros pobres. 
Diferentes estratégias de controle e extermínio, voltadas a essa população, começaram a ser implementadas no período pós-abolição, dando-se início a um projeto - genocida, como sugere Flauzina (2008) - de Estado até hoje inacabado, mas em plena e contínua execução, como fazem prova os casos abordados no início deste estudo. Seja pela via da "higienização" das cidades, da criminalização de condutas como, por exemplo, a "vadiagem" e a "capoeira", ou, ainda, pela via do fomento à imigração europeia, o objetivo era o "branqueamento" de nossa população - ideal perseguido com vigor no período republicano.

É importante observar, a propósito, que, antes mesmo da promulgação da Constituição da República (1891), erige-se um Código Penal (1890) que criminaliza a prática de condutas relacionadas aos ex-escravos 7 . De acordo com Flauzina (2008, p. 82), isso evidencia que "o fim do regime de trabalhos forçados reclamou prioritariamente um instrumento de repressão, deixando para segundo plano uma carta de declaração de direitos e princípios que regulamentasse a vida em sociedade."

Por seu turno, os projetos imigrantistas do século XIX também estavam profundamente alicerçados na questão racial. Aqui, o "branqueamento" da população brasileira, a ser alcançado por meio do fomento à imigração europeia, buscava fazer com que o aporte ao Brasil de imigrantes europeus se transformasse em condição de possibilidade para a proeminência desta raça "superior" (branca) em detrimento das raças "inferiores" (negras).

Essa perspectiva fica bastante evidente no ensaio que João Batista Lacerda, o então diretor do Museu Nacional do Rio de Janeiro, apresentou em Londres, em 1911, durante o I Congresso Universal das raças $^{8}$. No texto, Lacerda mostrava-se otimista quanto ao branqueamento da população brasileira no decurso do século XX: “as correntes de imigração

\footnotetext{
7 O Código Penal republicano de 1890 (Decreto no 847/1890), em seu capítulo XII, intitulado “Dos vadios e Capoeiras", tipificava a prática em seu art. 402, assim redigido: "Art. 402. Fazer nas ruas e praças públicas exercício de agilidade e destreza corporal conhecida pela denominação de capoeiragem: andar em carreiras, com armas ou instrumentos capazes de produzir lesão corporal, provocando tumulto o desordens, ameaçando pessoa certa ou incerta, ou incutindo temor de algum mal; Pena de prisão celular por dois a seis meses. Parágrafo único. É considerado circunstância agravante pertencer a capoeira em alguma banda ou malta." O inteiro teor do referido Decreto pode ser consultado em: <http://www.planalto.gov.br/ccivil_03/decreto/1851-1899/d847.htm>. Acesso em: 26 mar. 2020.

8 "João Baptista de Lacerda (1846-1915) foi o cientista eleito para representar o país naquele evento. Intelectual de renome nacional, Lacerda formara-se em medicina pela Faculdade do Rio de Janeiro, era autor de pesquisas na área de fisiologia e microbiologia, tendo exercido atividades de relevo durantesua carreira. Foi ministro da Agricultura e, no Museu Nacional, chefe do Laboratório Experimental e subdiretor das seções de zoologia, antropologia e paleontologia. Boa parte de suas investigações resultou em artigos publicados na renomada Revista do Museu Nacional. Foi também diretor dessa instituição, além de presidente da Academia Nacional de Medicina." (SCHWARCZ, 2011, p. 226).
} 
europeia, que aumentam a cada dia e em maior grau o elemento branco desta população, terminarão, ao fim de certo tempo, por sufocar os elementos dentro dos quais poderiam persistir ainda alguns traços do negro." (LACERDA apud SCHWARCZ, 2011, p. 239). Na "profecia" de Lacerda, "em três gerações, ofereceríamos um exemplo ao mundo: mostraríamos uma redenção e 'redução' étnica, bem no alvorar do novo século", na medida em que "a raça negra desapareceria entre os brasileiros e, junto com o incentivo à imigração europeia, a nação seria definitiva e finalmente branca." (SCHWARCZ, 2011, p. 231).

Para ilustrar sua tese acerca da "depuração" da raça da população brasileira, Lacerda recorreu à tela de Modesto Brocos intitulada "A redenção de Cam", pintada em 1895. A legenda aposta por Lacerda à tela indica a leitura por ele feita da obra - e a interpretação por ele recomendada, portanto: "O negro passando a branco, na terceira geração, por efeito do cruzamento de raças" (LACERDA apud SCHWARCZ, 2011, p. 228):

Imagem 2: A redenção de Cam

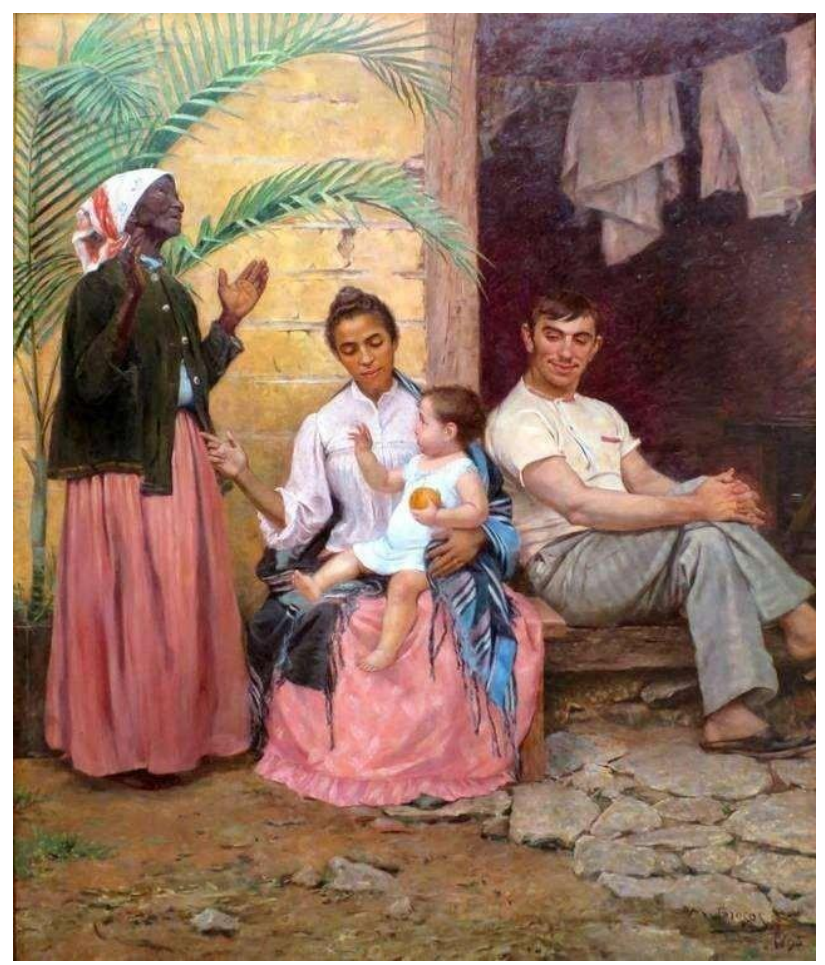

Fonte: Edusp ${ }^{9}$

\footnotetext{
${ }^{9}$ Imagem disponível em: <http://homologa.edusp.usp.br/mais/a-tela-a-redencao-de-cam-e-a-tese-dobranqueamento-no-brasil/>. Acesso em: 26 mar. 2020.
} 
Esse contexto, na análise de Seyferth (2002, p. 119), evidencia que "noção hierárquica de civilização estava por trás de certos desideratos biológicos, fazendo da cor branca um indicador de superioridade, mesmo na ausência de um discurso explicitamente racista."

É justamente nesse cenário que a população negra se encontrou ao fim da escravidão, tendo de competir com os imigrantes europeus, empobrecidos, mas que chegam ao país com aspirações de construir aqui sua existência, uma vida digna, acostumados com a ordem capitalista e com o trabalho manual, o qual viam como edificante. Nesse sentido, de acordo com lanni (1972, p. 49-50), "o negro cidadão não é o negro escravo transformado em trabalhador livre. O negro cidadão é apenas o negro que não é mais juridicamente escravo", o que significa que "ele foi posto na condição de trabalhador livre, mas nem é aceito plenamente ao lado de outros trabalhadores livres, brancos, nem ainda se modificou substancialmente em seu ser social original". Assim, trata-se "do escravo que ganhou a liberdade de não ter segurança; nem econômica, nem social, nem psíquica."

Nesse sentido, "o cativo que sai da casa do senhor ou da fazenda, de um dia para outro, sem ter sido preparado ou ter-se apropriado dos meios sócio-culturais necessários à vida nas novas condições, não é ainda um homem livre." Pelo contrário, trata-se de "uma pessoa cujo estado alienado vai manifestar-se agora plenamente, pois que é na liberdade que ele compreenderá que foi e é espoliado." Uma vez livre, "ele estará só e escoteiro dos meios de subsistência, dos instrumentos de produção", quando então "tomará consciência de que não tem meios de consegui-los, salvo pela venda da sua força de trabalho, operação essa para a qual não foi preparado." (IANNI, 1972, p. 49-50).

Do mesmo modo, na incipiente República, a aliança do saber médico com o saber jurídico - ambos em sintonia com as teses lombrosianas acerca do fenômeno do crime e da criminalidade - produziu um discurso "higienista" que cumpriu com um papel importante no controle e estigmatização do povo negro. A partir de então, além da segregação pela via da imposição de penas privativas de liberdade, iniciou-se um processo de "patologização" da população negra, por meio da sua associação ao risco de proliferação de doenças relacionadas às habitações coletivas nas quais vivam nos centros urbanos (cortiços). Esse discurso contribuiu para a segregação espacial dessa população, por meio da sua expulsão para espaços periféricos, criando-se, assim, territorialidades excludentes que até hoje marcam de modo indelével as cidades brasileiras (VAZ, 1994; CHALHOUB, 1996; SOUZA, 2000; COELHO, 2014), como se evidencia da imagem a seguir reproduzida, a qual ilustra, de um modo muito claro, essa realidade: 


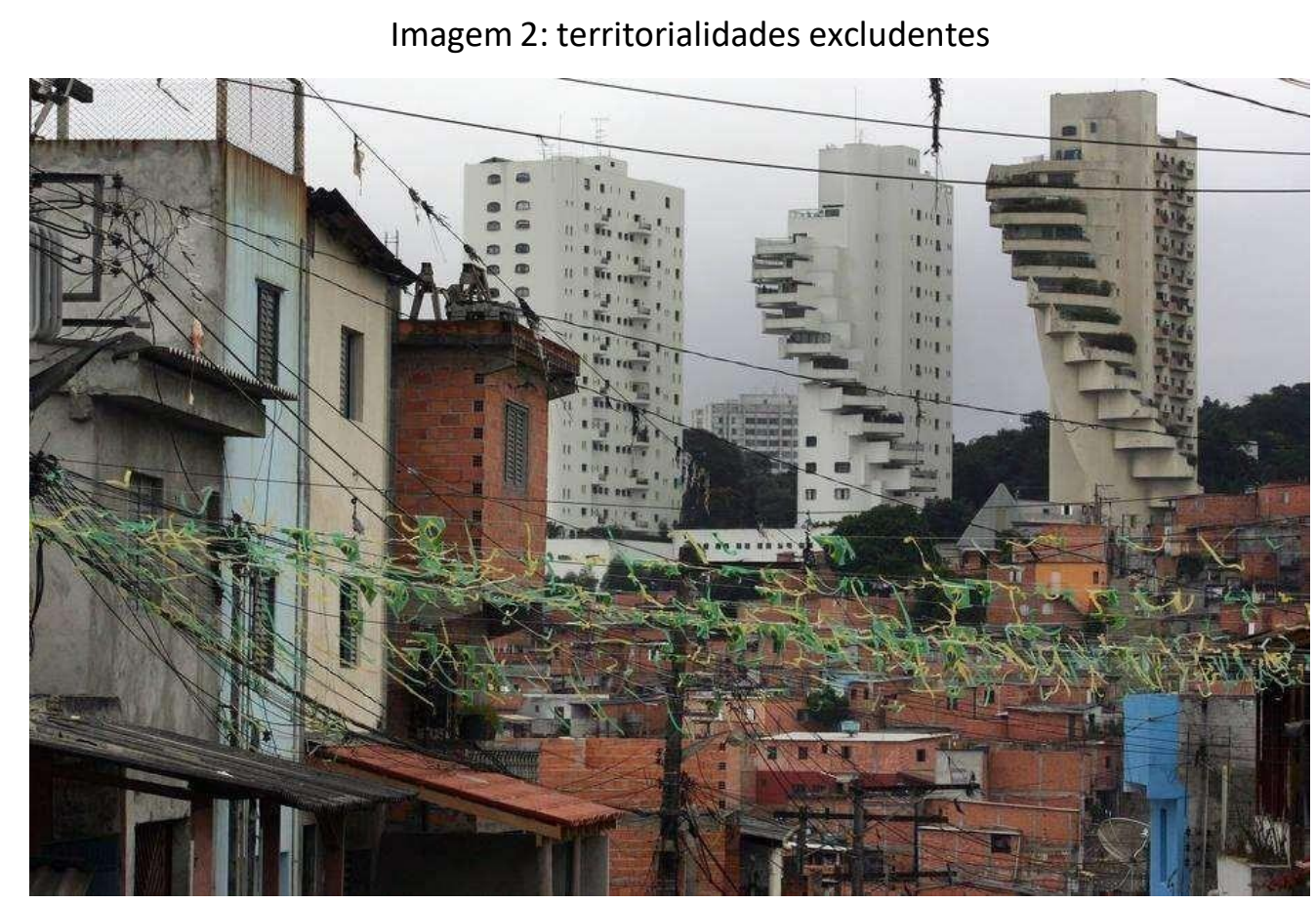

Fonte: Clayton de Souza (Jornal Estadão) ${ }^{10}$

Assim, deveras importante salientar que, na atualidade, a par de dados estatísticos e das corriqueiras divulgações midiáticas, é possível auferir que as vidas negras estão sendo tratadas tal qual há quinhentos anos atrás, como coisas. E, como aduz Schwarcz $(2019$, p. 32), "se hoje em dia as teorias raciais saíram de voga, se o conceito biológico de raça é entendido como falacioso e totalmente equivocado em suas decorrências morais, ainda utilizamos a noção de 'raça social'" - a já denominada "ralé de novos escravos", na léxica de Souza (2017). Por outro lado, ainda "tendemos a criar um plus perverso de discriminação, que faz com que negros e negras morram mais cedo e tenham menor acesso aos direitos de todos os cidadãos brasileiros." (SCHWARCZ, 2019, p. 32).

A violência contra negros, sobretudo a institucionalizada, como é o caso do tratamento violento perpetrado por policiais contra esta população - a exemplo dos casos Marielle, Evaldo e Ágatha -, demonstra que as suas vidas são cada vez mais passíveis de eliminação impune. Pode-se, nesse sentido, diante da magnitude do fenômeno morte associado à população negra

\footnotetext{
${ }^{10}$ Disponível em: <https://economia.estadao.com.br/noticias/geral,2-7-das-familias-brasileiras-ficamcom-um-quinto-da-renda-gerada-no-pais-mostra-ibge,70003037000>. Acesso em: 26 mar. 2020.
} 
do Brasil, afirmar a existência de uma verdadeira política de extermínio, ou uma necropolítica conceito que mais adiante pretende-se explorar com a devida atenção.

Segundo dados levantados em um raro estudo de Von Eschwege (1944), em 1814, a taxa de mortalidade de negros era de 53,8 por mil, contra 28,3 por mil de brancos. Tais estatísticas demonstram que a banalização da violência contra a vida do negro não é fenômeno da contemporaneidade, mas sim evidência de um modelo de racismo que é estrutural, o que significa dizer, de acordo com Silvio Almeida (2018, p. 38-39, grifos do autor), que ele se constitui como "uma decorrência da própria estrutura social, ou seja, do modo 'normal' com que se constituem as relações políticas, econômicas, jurídicas e até familiares"; não se trata, pois, de "uma patologia social e nem um desarranjo institucional." Nesse marco, "comportamentos individuais e processos institucionais são derivados de uma sociedade cujo racismo é regra e não exceção." Do ponto de vista teórico, portanto, "o racismo, como processo histórico e político, cria as condições sociais para que, direta ou indiretamente, grupos racialmente identificados sejam discriminados de forma sistemática."

Isso, em alguma medida, permite compreender porque, segundo dados oriundos do site Nações Unidas Brasil (2018), sete em cada dez pessoas assassinadas no país são negras. Do mesmo modo, o racismo estrutural configura uma chave de compreensão para os dados apresentados pelo Instituto de Pesquisa Econômica Aplicada - IPEA, no Relatório Atlas da Violência relativo ao ano de 2018 , os quais apontam que " $71,5 \%$ das pessoas assassinadas a cada ano no país são pretas ou pardas." (IPEA, 2018). Da mesma forma, o racismo estrutural encontra evidência no Índice de Vulnerabilidade Juvenil à Violência e Desigualdade Racial, o qual aponta que um jovem negro, no Brasil, apresenta chances de ser vítima de homicídio, em média, 2,5 vezes superior às chances de um jovem branco (FÓRUM BRASILEIRO DE SEGURANÇA PÚBLICA, 2017).

Esses dados são ratificados por pesquisa recentemente divulgada pelo Fórum Brasileiro de Segurança Pública. O relatório denominado “Anuário Brasileiro de Segurança Pública - 2019" apresenta dados segundo os quais, do total de mortes intencionais no Brasil no decorrer do ano de 2018, 11 em cada 100 homicídios foram ocasionadas pelas Polícias, contabilizando-se 17 assassinatos por dia - o que conduz a um total de 6.220 vítimas. Destas, a grande maioria são homens $(99,3 \%)$, jovens $(77,9 \%)$ e negros $(75,4 \%)$ (FÓRUM BRASILEIRO DE SEGURANÇA PÚBLICA, 2019).

Essa estatística coloca o Brasil no ranking das polícias que mais produzem mortes em sua atuação cotidiana no âmbito latino-americano, juntamente com a Colômbia (onde a polícia 
é responsável por 1,5\% do total de homicídios), El Salvador (país no qual a polícia é responsável por $10,8 \%$ do total de homicídios, o qual, por sua vez, é $118 \%$ superior ao número de assassinatos do Brasil) e Venezuela (onde as forças policiais são responsáveis por $25,8 \%$ dos homicídios) (BUENO; MARQUES; PACHECO; NASCIMENTO, 2019, p. 61).

Tais dados apontam para o fato de que, seguindo uma tradição que tem origem no sistema escravocrata e que ganha contornos ainda mais evidentes na contemporaneidade, a população negra é a população que mais tem sofrido com a violência no Brasil - incluindo a policial -, a qual aterroriza os moradores das comunidades, os quais vivem sob forte tensão e na mira da guerra entre traficantes e policiais.

Com efeito, a partir da análise de Bueno et al (2019), os dados estatísticos levantados pelo Fórum Brasileiro de Segurança Pública, na esteira de outros estudos já produzidos, corroboram que: a) as ações letais da polícia ocorrem em territórios de baixa renda; b) atingem jovens do sexo masculino; e c) não estão aleatoriamente distribuídas, vitimando mais negros do que brancos. Ademais, os números de violência letal despendida pelas forças policiais formam uma curva ascendente, conforme ilustra o gráfico a seguir:

Gráfico 1: Mortes decorrentes de intervenções policiais em serviço e fora de serviço, 2013 a 2018

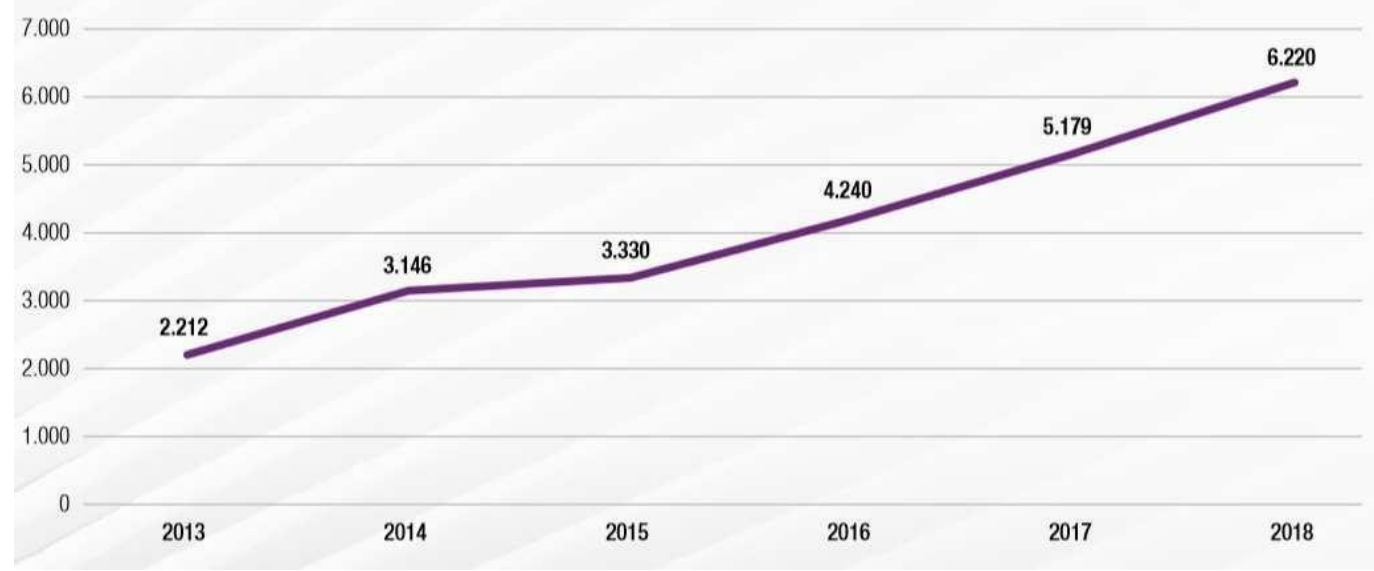

Fonte: Fórum Brasileiro de Segurança Pública (2019, p. 66)

Isso permite concluir que a escravidão e a violência que a ela subjaz moldou o modus operandi das instituições brasileiras responsáveis pelo tema da segurança pública, direcionando seus alvos para aqueles estratos que representaram, ao longo da história, algum tipo de "risco" para aqueles que ocupam espaços privilegiados de poder. Do "vadio" e do "capoeira" da 
incipiente República, é possível perceber uma linha contínua que orienta as práticas arbitrárias e violentas da(s) polícia(s) até a figura do "traficante" na contemporaneidade e, correlatamente, explica a monotonia cromática dos corpos caídos na esteira dessas práticas (WERMUTH, 2018).

Mesmo que o racismo não seja mais aceito como teoria científica, é possível observar que ele "continua plenamente atuante, enquanto ideologia social, na poderosa 'teoria do senso comum', aquela que age perversamente no silêncio e na conivência do dia a dia" (SCHWARCZ, 2019 , p. 35). Nesse sentido, o racismo pode ser compreendido como base fundante da política de morte que se estabelece, no Brasil, em relação à população negra pauperizada. É sobre essa necropolítica, em curso no Brasil, que se ocupa o tópico a seguir.

\section{ACHILLE MBEMBE E A NECROPOLÍTICA: uma (possível) chave de compreensão da violência policial contra pessoas negras e pobres no Brasil contemporâneo}

"Ai, esta terra ainda vai cumprir seu ideal Ainda vai tornar-se um imenso Portugal Ai, esta terra ainda vai cumprir seu ideal Ainda vai tornar-se um império colonial" (Chico Buarque de Holanda. Fado tropical)

O filósofo camaronês Achille Mbembe é hoje um dos mais proeminentes pensadores do pós-colonialismo. O autor adverte, no início do ensaio Necropolítica, que sua proposta baseiase nas obras de Michel Foucault, Hannah Arendt e Giorgio Agamben, na medida em que o texto é embasado no conceito de biopoder, em sua relação com as noções de soberania e estado de exceção. Mbembe (2018a, p. 10-11) salienta, então, que sua preocupação gira em torno daquelas "formas de soberania cujo projeto central não é a luta pela autonomia, mas 'a instrumentalização generalizada da existência humana e a destruição material de corpos humanos e populações'." Isso porque compreende que essas formas de soberania, tal como o campo agambeniano ${ }^{11}$, "constituem o nomos do espaço político em que ainda vivemos." (MBEMBE, 2018a, p. 11).

\footnotetext{
${ }^{11}$ De acordo com Agamben (2015, p. 42-43), "o campo é o espaço que se abre quando o Estado de Exceção começa a se tornar a regra. Nele, o Estado de Exceção, que era essencialmente uma suspensão temporal do ordenamento, adquire uma ordem espacial permanente que, como tal, fica, porém, constantemente fora do ordenamento normal. Deste modo, o campo é um pedaço de território que é colocado fora do ordenamento jurídico normal, mas não é, por isso, simplesmente um espaço exterior. O que nele é excluído, segundo o significado etimológico do termo exceção (ex-capere), é capturado fora, incluído através da própria exclusão. Mas aquilo que, desse modo, é antes de tudo capturado no ordenamento é
} 
Seria possível afirmar que a noção de biopoder de Michel Foucault ${ }^{12}$ é suficiente para compreender o modo como, nos dias atuais, a guerra - exercício do direito de matar para manutenção da soberania - tem por objetivo precípuo a morte daquele que é elencado como inimigo? (MBEMBE, 2018a). Esta é a pergunta central da pesquisa realizada pelo camaronês no ensaio em questão.

Na perspectiva em tela, a escravidão pode ser considerada uma das primeiras vivências biopolíticas e se concatena com o surgimento do terror moderno. De acordo com Mbembe (2018, p. 35), é na colônia que a paz se torna uma guerra permanente e se assemelham às fronteiras, porque nelas habitam os "selvagens" e, "aos olhos do conquistador, 'vida selvagem" é apenas outra forma de 'vida animal', uma experiência assustadora, algo radicalmente outro (alienígena), além da imaginação ou da compreensão." Aos selvagens, portanto, falta o "caráter específico humano", ou seja, "a realidade especificamente humana, o que permitiu a afirmação de Hannah Arendt (2012, p. 277) de que "quando os europeus os massacravam, de certa forma não sentiam que estivessem cometendo um crime contra homens."

A colônia, assim, configura-se como uma zona na qual guerra e desordem assumem polos horizontais e, ocasionalmente, sobrepõem-se, provocando uma verdadeira indistinção entre direito e violência - tal como no estado de exceção agambeniano (AGAMBEN, 2004). As colônias "são o local por excelência em que os controles e as garantias de ordem judicial podem ser suspensos - a zona em que a violência do estado de exceção supostamente opera a serviço da civilização" (MBEMBE, 2018a, p. 35). O espaço onde se situam essas zonas era a própria matéria-prima da soberania porque, ao ocupar um determinado território, relega-se o colonizado ao status de sujeito-objeto. Com efeito, o colonizado, agora, está em uma terceira zona, de modo que

o direito soberano de matar não está sujeito a qualquer regra nas colônias. Lá, o soberano pode matar a qualquer momento ou de qualquer maneira. A guerra colonial não está sujeita a normas legais e institucionais. Não é uma atividade codificada legalmente. Em vez disso,

o próprio Estado de Exceção. Ou seja, o campo é a estrutura na qual o Estado de Exceção, sobre cuja decisão possível se funda o poder soberano, é realizado de modo estável."

${ }^{12} \mathrm{Na}$ obra foucaultiana, as categorias biopolítica e biopoder - ora utilizadas como sinônimo, ora não pretendem abarcar a complexa questão da normalização biológica dos seres humanos, no caminho que o autor trilhava na investigação do problema da governamentalidade. Por biopolítica, Foucault vai designar o movimento segundo o qual, a partir do século XVIII, a vida biológica começa a se converter em objeto da política, ou seja, a vida biológica passa a ser produzida e, além disso, administrada, com a particularidade de que, mesmo sendo objeto de normalização, a vida biológica nunca fica exaustivamente retida nos mecanismos que pretendem controlá-la, pois sempre os excede e deles, por fim, escapa (CASTRO, 2011). 
o terror colonial se entrelaça constantemente com um imaginário colonialista, caracterizado por terras selvagens, morte e ficções que criam o efeito de verdade. (MBEMBE, 2018a, p. 36).

O racismo, nos moldes foucaultianos, assume, aqui, uma posição fundamental: "a raça foi a sombra sempre presente no pensamento e na prática das políticas do Ocidente, especialmente quando se trata de imaginar a desumanidade de povos estrangeiros - ou a dominação a ser exercida sobre eles." (MBEMBE, 2018a, p. 18). Em Foucault (2010, p. 214), o racismo se constitui em condição de possibilidade para a aceitabilidade do "fazer morrer" em um regime alicerçado na economia do biopoder:

no contínuo biológico da espécie humana, o aparecimento das raças, a distinção das raças, a hierarquia das raças, a qualificação de certas raças como boas e de outras, ao contrário, como inferiores, tudo isso vai ser uma maneira de fragmentar esse campo do biológico de que o poder se incumbiu; uma maneira de defasar, no interior da população, uns grupos em relação aos outros. [...] Isso vai permitir ao poder tratar uma população como uma mistura de raças ou, mais exatamente, tratar a espécie, subdividir a espécie de que ele se incumbiu em subgrupos que serão, precisamente, raças. Essa é a primeira função do racismo: fragmentar, fazer cesuras no interior desse contínuo biológico a que se dirige o biopoder.

A segunda função do racismo radica na legitimação da morte do "outro" a partir de uma maneira inteiramente nova: "a morte do outro, a morte da raça ruim, da raça inferior (ou do degenerado, ou do anormal), é o que vai deixar a vida em geral mais sadia." Em outras palavras, "a função assassina do Estado só pode ser assegurada, desde que o Estado funcione no modo do biopoder, pelo racismo." (FOUCAULT, 2010, p. 215).

É por isso que, segundo Ayub (2014, p. 109), “o racismo é o mais novo disfarce com o qual entra em cena o poder de soberania." Segundo Mbembe (2018a, p. 41), a soberania, nesse caso, "é a capacidade de definir quem importa e quem não importa, quem é 'descartável' e quem não é." Nesse sentido, a raça funcionaria como verdadeiro "dispositivo de segurança fundado naquilo que poderíamos chamar de princípio do enraizamento biológico pela espécie. A raça é ao mesmo tempo ideologia e tecnologia de governo." (MBEMBE, 2018b, p. 75).

A ocupação colonial tardia - cuja forma mais bem-sucedida, de acordo com o filosofo camaronês é a ocupação colonial contemporânea da Palestina - apresenta uma combinação entre o disciplinar, a biopolítica e a necropolítica, sendo que, de acordo com Mbembe (2018a), são três as características principais na operacionalização do terror pelo necropoder na 
contemporaneidade: fragmenta-se o território, proíbem-se acessos e se expandem assentamentos.

A fragmentação territorial constrói uma série de estradas, túneis e pontes que, em um território, permitem a sobreposição de duas ou mais geografias. Tal processo de fragmentação territorial e sobreposição de geografia, assemelha-se com os "guetos" urbanos atuais. A expressão "gueto", origina-se na Europa Ocidental, local no qual a palavra era utilizada para determinar residências judaicas (WACQUANT, 2004). Os locais subversivos recebiam a seguinte denominação: "favelas". Com a era progressista, sua semântica se modificou e referia-se "à intersecção entre o bairro étnico e a favela, onde a segregação se aliava à dilapidação das moradias, exacerbando os males urbanos e inibindo a participação na vida social" (WACQUANT, 2004, p. 264, grifo do autor). Após a Segunda Guerra Mundial, a compreensão desse termo se contraiu ainda mais: passou a ser entendido como o "o confinamento forçado de afroamericanos em distritos centrais compactos e dilapidados" (WACQUANT, 2004, p. 264, grifos do autor), com o objetivo principal de isolar os descendentes de escravos daqueles de etnia branca. Separar, em outras palavras, a colônia da metrópole. O colonialismo e a escravidão são as instituições mais brutais de violência social para a constituição dos guetos (WACQUANT, 2004).

Desse modo, na contemporaneidade há um rebaixamento do gueto à favela, e todo espaço territorial em que haja um "expurgo" de raça e da classe economicamente mais baixa, acaba por originar um espaço no qual o branco não chega, porque perigoso (WACQUANT, 2004). A relação de poder que se encontra nos guetos urbanos atuais, demonstra-se cada vez mais complexa por causa da arquitetura e da expansão demográfica de um modo geral. Há um liame forte entre a geografia das cidades com as relações de poder. As cidades precisaram criar estruturas que comportassem o máximo de pessoas no menor espaço territorial possível. Delimitaram-se marcos na metrópole, que dada a sua multiplicidade, geraram choques dentro do espaço urbano (CARLOS, 2007). É em razão da não justaposição, mas sim, da interposição, composição desses marcos, que os espaços fragmentados da cidade se chocam inevitavelmente - uma vez que se movem de acordo com estratégias de controle (CARLOS, 2007).

Stephen Graham (2016), em estudo a respeito do que ele denomina de um "novo urbanismo militar" em andamento nas grandes cidades mundiais, explica que esse novo fenômeno busca controlar, pacificar ou se aproveitar de determinadas populações, recorrendo a invocações de estados de emergência para justificar ataques violentos aos direitos humanos dessas pessoas. Marcelo Lopes de Souza, na apresentação dessa mesma obra aos leitores brasileiros, salienta que a militarização da questão urbana, no Brasil, tem como pano de fundo 
justamente esses sentimentos difusos de medo e insegurança alimentados pela mídia e pelo sistema político-eleitoral.

É nesse sentido que se faz necessário refletir a relação que há entre o mundial e o local para se compreender a modernidade (CARLOS, 2007). A urbanização é um processo que dá origem ao "fenômeno da concentração-centralização de poder que permite a extensão da periferia e do tecido urbano, integrando parcelas do espaço através da gestão (CARLOS, 2007, p. 41)", e revela, entretanto, relações específicas de dependência e hierarquia social. Aqueles com menores índices de concentração de renda acabaram por habitar nos guetos e favelas de suas cidades, uma vez que o espaço central é destinado aqueles com maiores rendas. Essa divisão denota o racismo estrutural e a desigualdade econômica ainda presentes - mesmo que veladas - nesta geração. Nesse sentido,

nos guetos formados pelos bairros nobres, as casas e mansões tornam-se construções fortificadas como se fossem prisões, mas aqui não há identidade aparente, posto que os muros separam $e$ isolam seus habitantes impedindo relações de vizinhança. Os condomínios fechados, que pontuam a periferia da mancha urbana da metrópole paulista, são a expressão máxima desse confinamento, pois além de rigidamente demarcadas, apresentam forte esquema de segurança $e$ controle. (CARLOS, 2007, p. 43-44, grifo nosso).

Imagem 3: Outra perspectiva das territorialidades excludentes

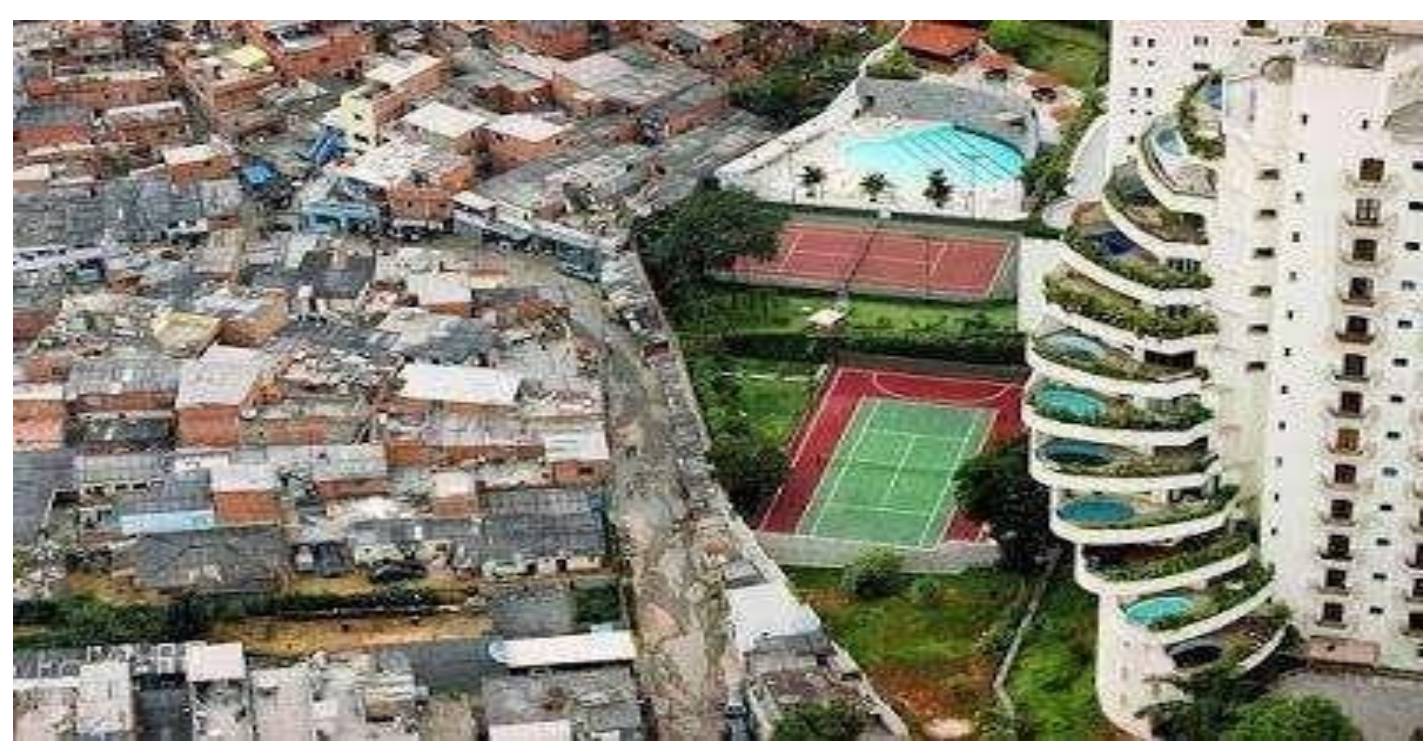

Fonte: Tuca Vieira (Folha de São Paulo) ${ }^{13}$

\footnotetext{
13 Imagem disponível em: <http://marlivieira.blogspot.com/2015/06/paraisopolis-e-os-limites-dasegregacao.html>. Acesso em: 27 mar. 2020.
} 
A imagem escolhida - dentre tantas outras que simbolizam o mesmo fenômeno na cartografia das cidades brasileiras - evidencia que as políticas adotadas atualmente continuam a criar fronteiras simbólicas, bem como a perpetuar uma narrativa em que o branco permanece no topo da pirâmide (SCHWARCZ, 2019). Uma nova onda conservadora tem atingindo países como o Estados Unidos, Hungria, Israel, Itália, Polônia, Rússia, com o objetivo de traçar o que seria a "verdadeira" narrativa histórica para esses povos (SCHWARCZ, 2019). Taís países têm ampliado fronteiras e fortificado muros, numa incessante luta contra o "outro" indesejável - a exemplo dos refugiados, apátridas, negros, pobres, mulçumanos, etc. Os Estados continuam a combinar o código binário inclusão (cultural) com exclusão (social), une ao mesmo passo que separa (SCHWARCZ, 2019) - tudo alicerçado sobre a perspectiva racista desvelada pela obra foucaultiana.

Nesse sentido, de acordo com Mbembe, a rápida circulação das cidades, os entrecruzamentos, tentam manter o "princípio da exclusão recíproca" de Frantz Fanon (1968): não existe possibilidade de conciliação entre as zonas habitadas pelos colonizados e as zonas habitadas pelos colonos, os últimos sempre estão "a mais". Há um simbolismo fundamental presente no topo na ocupação colonial moderna da palestina. O policiamento feito pelo ar, a militarização do espaço aéreo da Cisjordânia, demonstram, para o filósofo camaronês, que a necropolítica na contemporaneidade significa matar, mirar, com alta precisão ${ }^{14}$ - em um contexto de "estado de sítio", o qual permite "uma modalidade de crime que não faz distinção entre o inimigo interno e o externo", na medida em que "populações inteiras são o alvo do soberano". Nesse contexto, "as vilas e cidades sitiadas são cercadas e isoladas do mundo. A vida cotidiana é militarizada." Paralelamente a isso, "é outorgada liberdade aos comandantes militares locais para usar seus próprios critérios sobre quando e em quem atirar" - mesmo que isso implique, eventualmente, "danos colaterais" a exemplo dos casos Ágatha e Evaldo. E,

\footnotetext{
${ }^{14}$ É possível estabelecer uma conexão desse conceito até mesmo com a invenção dos fuzis. Esses foram criados para substituir os mosquetes em meados do século XIX, e partir de então, a tecnologia bélica se encarregou de aperfeiçoar as miras das armas. Segundo Foucault, as mudanças ocorridas entre o século XVIII e XIX se deslocam para a obtenção de um resultado específico que visa a um resultado ótimo, com o máximo de eficiência possível. É nesse contexto que se pode citar a invenção do fuzil: "mais preciso, mais rápido que o mosquete, valoriza a habilidade do soldado; mais capaz de atingir um alvo determinado, permitia explorar a potência de fogo ao nível individual; e inversamente fazia de cada soldado um alvo possível, exigindo pela mesma razão maior mobilidade; e assim ocasionava o desaparecimento de uma técnica das massas em proveito de uma arte que distribuía as unidades e os homens ao longo de linhas extensas, relativamente flexíveis e móveis." (FOUCAULT, 2010, p. 156-157).
} 
nesses espaços, "às execuções a céu aberto somam-se as matanças invisíveis" - que podem se referir a projetos de emancipação dessas populações, o que no Brasil é ilustrado pelo assassinato de Marielle Franco (MBEMBE, 2018a, p. 48-49).

Com efeito, a política descrita por Mbembe não diverge do cenário brasileiro contemporâneo: no Brasil, há uma licença para matar pobres e favelados, ratificada pelos próprios governos (PETRONE, 2020). As políticas adotadas pelo governador Wilson José Witzel (PSC) no Rio de Janeiro são exemplos de uma verdadeira política genocida:

Era uma vez um governador que gravou um vídeo afirmando que iria acabar com a bandidagem. Era uma vez um governador que comandou pessoalmente, de dentro de um helicóptero blindado, uma operação policial em que agentes da segurança pública atiraram de cima para baixo, a esmo, em uma favela, atingindo inclusive uma tenda evangélica. Era uma vez um governador que publicou tudo isso, com orgulho, nas páginas institucionais do governo do Estado. Essa história de terror é a realidade desesperadora do Rio de Janeiro. (PETRONE, 2020, p. 1).

Witzel se traveste com o discurso de uma pretensa preocupação com a segurança pública, e empodera a polícia a mirar diretamente na cabeça de "bandidos", sem lembrar, no entanto, que aqueles que considera perigosos, são muitas vezes moradores das favelas sem quaisquer relações com crimes (PETRONE, 2020). O incentivo por parte do governador para a adoção de franco-atiradores em operações militares é mais um indicativo de que no Brasil se tem esquecido de princípios como o devido processo legal e a ampla defesa, e tem-se partido para a punição arbitrária de crimes com a morte - em um país em que a pena de morte é vedada.

Alguns dados sobre a intervenção federal na segurança pública do Rio de Janeiro também permitem ratificar essas afirmações. No relatório intitulado "Intervenção Federal: um modelo para não copiar", elaborado pelo Observatório da Intervenção, aponta-se que, dentre os crimes que compõem o indicador "letalidade violenta", o número que subiu em todas as regiões do Rio foi o de mortes provocadas por agentes do Estado. O relatório demonstra que entre os meses de fevereiro a dezembro de 2018 houve um aumento de $33,6 \%$ nesse indicador em relação ao ocorrido no ano de 2017, totalizando 1.375 mortes. Quanto aos agentes de segurança, verificou-se a morte de 99 pessoas e mais 140 feridos. Um dos dados mais alarmantes apresentados pelo referido relatório refere-se ao número ocorrências de tiroteiose disparos de armas de fogo: verificou-se que ocorreram, durante a intervenção, 8.613 tiroteios e disparos de armas de fogo, um número $56,6 \%$ maior em relação ao ano de 2017. Quando 
ocorrem casos em que são vitimadas 3 ou mais pessoas, utiliza-se o termo "chacina": durante a intervenção, foram registradas 54 chacinas, o que resultou na morte de 216 pessoas, número 63,6\% maior que no ano de 2017 (RAMOS, 2019).

Ocorre que a violência a que alguns cidadãos estão sujeitos, em face a outros, é distribuída na cidade de forma extremamente desigual. Sobre o tema, destaca-se estudo realizado por Luiz Antonio Machado da Silva e Márcia Pereira Leite (2007), intitulado "Violência, crime e polícia: o que os favelados dizem quando falam desses temas?", no qual os pesquisadores, reunindo 150 moradores de mais de 40 favelas, realizaram conversas com tais pessoas a fim de saber qual é a percepção dos próprios moradores dos locais que são objeto das ações em estudo neste trabalho.

O principal foco dos relatos obtidos nos encontros dos grupos foram as violências sentidas, oriundas tanto por parte dos criminosos, quanto dos policiais. A forma de percepção, contudo, é diferente. Em relação aos policiais, os moradores os responsabilizam em muitos relatos pela insegurança e perigos que vivenciam, em razão da realização de incursões violentas, nas quais os policiais não buscam diferenciar quem são os moradores e quem são os criminosos (SILVA; LEITE, 2007).

Dos relatos dos moradores, os autores concluíram, principalmente, que o sentido que eles imprimem às suas falas são referentes à quebra de rotina que as violências causam em suas vidas. Essa percepção é dirigida tanto às incursões policiais violentas, quanto a dos traficantes e aos confrontos armados entre bandos diferentes. Os autores entendem que as interrupções de rotina sentidas pelos moradores leva a um constante sentimento de medo, que, ademais, atinge toda a população da cidade, mas que, especificamente em relação às favelas, representa o bloqueio das condições objetivas para continuar a vida de forma estável. Contudo, o medo, que, na definição dos autores, trata-se de um medo social difuso, "acaba por produzir demandas de uma recomposição das rotinas pela força, fechando assim um círculo de ferro que reproduz indefinidamente a violência como elemento estruturador fundamental” (SILVA; LEITE, 2007).

De acordo com uma pesquisa realizada pelo Instituto de Pesquisa Econômica Aplicada (Ipea), bem como pelo Fórum Brasileiro de Segurança, o Atlas da Violência revela que entre 2007 a 2017, houve um crescimento de $33,1 \%$, na contagem de homicídios de negros (PETRONE, 2020). Marielle Franco, Evaldo Rosa dos Santos, Luciano Macedo e Agatha Vitória Sales Félix são vítimas desta verdadeira política de morte que ganha, inclusive, chancela do atual Presidente da República. 
Com a potencialização dos aparatos tecnológicos - como, por exemplo, jatos de reconhecimento aéreo, helicópteros de assalto, satélites de observação da Terra - é possível executar uma "guerra estrutural" em que se combinam "táticas de sítio medieval adaptada para a expansão da rede em campos de refugiados urbanos." (MBEMBE, 2018a, p. 47). Há uma intensa correlação entre os poderes disciplinar, biopolítico e necropolítico: dominam-se os colonizados de modo absoluto. Nesse contexto, o capitalismo, racismo e colonialismo se constituem enquanto peças de uma mesma engrenagem (PELBART, 2020).

Como exemplo do "mirar com alta precisão", é possível citar o quinto episódio da quarta temporada da série britânica Black Mirror, intitulado Metalhead. A ausência de cor e a trilha sonora intensa do episódio revela a atmosfera pós-apocalíptica do cenário: "os vencedores contemplam a vida por ninguém vivida e os corpos dos que estão prostrados no chão." (PANDOLFO; LINCK, 2018, p. 676). Ao buscar uma caixa em um depósito, Bella e Tony são alvejados por rastreadores do cão cabeça-de-metal. Tony e Clarke são vitimados pelo exbicho enquanto Bella foge deste: "O humano exhumado aí persegue certamente o seu fim, ele segue para; segue e para, cansa, sonha, ama. Cogita. O exbicho não; encontra-se incessantemente ligado - num breve intervalo de tempo recarrega-se automaticamente, exorganicamente." (PANDOLFO; LINCK, 2018, p. 678).

O cão cabeça-de-metal faz referência a produções tecnológicas da empresa Boston Dynamics, - responsável por criar pós-animais hiper-reais - mais especificamente, dos bigdogs, tecnologia para fins militares que permite o controle remoto de cães robôs (PANDOLFO; LINCK, 2018). Entretanto, o episódio não deixa explícito que o metalhead era controlado por alguém. Ainda que Bella tenha tentado reiteradamente fugir do exbicho, este consegue rastrear seu sangue, visualizar topograficamente o local, ouvir sons à longa distância, com um único objetivo: matar seu alvo. Mais: depois de abatido, o cão lança contra sua vítima mais rastreadores, e outros cães saem em busca da humana exhumada. Não há como fugir.

Tal distopia revela uma realidade atual: o exercício do poder de morte não é tão somente dos Estados (MBEMBE, 2018a): "Milícias urbanas, exércitos privados, exércitos de senhores regionais, segurança privada e exércitos de Estado proclamam, todos, o direito de exercer violência ou matar." (MBEMBE, 2018a). Entretanto, as milícias não são apenas regionais, precisam de apoio político e comunitário, e por essa razão são um grande exemplo de "como a violência se instalou no país, ganhando os espaços aonde a lei não chega ou abre a mão de chegar." (SCHWARCZ, 2019, p. 182). 
As guerras, portanto, não ocorrem mais entre Estados soberanos apenas. Elas são travadas entre grupos armados - revestidos pelo Estado - contra grupos sem Estado, mas, que controlam territórios como se estatizados fossem (MBEMBE, 2018a). O filósofo camaronês também conclui que a noção de biopoder foucaultiana é insuficiente para exemplificar as formas contemporâneas de assassínio em que se criam "mundos de morte" com foco na morte eficiente - destruição máxima - de pessoas. No necropoder, as fronteiras entre resistência e suicídio, sacrifício e redenção, martírio e liberdade desaparecem. (MBEMBE, 2018a).

A teoria de Mbembe, portanto, se mostra essencial para entender o contemporâneo, porque multidisciplinar: nela, há uma análise social, política, filosófica, arquitetônica, geográfica. Para além, demonstra-se altamente interdisciplinar. Permite refletir a teoria foucaltiana e agambeniana de tal modo que a cidade, em sua arquitetura, transcreve sua memória: " $\mathrm{A}$ memória articula espaço e tempo, ela se constrói a partir de uma experiência vivida num determinado lugar. Produz-se pela identidade em relação ao lugar, assim lugar e identidade são indissociáveis." (CARLOS, 2007, p. 49). A partir dessa memória, é possível compreender o presente. A urbanidade possui uma relação dialética entre o local e a sociedade que está inserida (PEREIRA, 2018).

Por outro lado, a partir dos dados apresentados na seção anterior, constata-se que há seletividade na violência urbana brasileira. A necropolítica, nesse contexto, é a política da execução dessa seletividade que tem por fim ratificar o direito - velado - do Estado e de organizações não-estatais, de matar. O Estado Democrático de Direito no Brasil deve ser fortificado. Todos os dias, os jornais noticiam casos como os expostos no presente estudo que são exemplos da emergência de um estado excepcionado. $O$ apoio que o governo atual demonstra às manifestações de ódio e preconceito contra a parcela da população brasileira "indesejável", é mais uma evidência de que o país se tornou uma "democradura" - democracia com vestes de ditadura -, de acordo com Schwarcz (2019).

Na contemporaneidade, "com o divórcio entre os interesses do capitalismo financeiro global e as formas políticas do Estado Democrático de Direito, criminalizar os pobres, a miséria e a própria política passou a ser a estratégia do capital." (PEREIRA, 2018, p. 253). Criminaliza-se a pobreza, os movimentos sociais, a política, a própria vida (PEREIRA, 2018). E o capital, para Pelbart (2003), nunca esteve tão entranhado na psique humana, bem como na vida - recurso essencial para o apoio às reivindicações sociais. 


\section{CONSIDERAÇÕES FINAIS}

A partir da análise da escravidão enquanto modelo no qual foi forjada a sociedade brasileira, alicerçado em uma lógica violenta e racista, este estudo buscou, por meio do recurso ao conceito de necropolítica cunhado na obra do filósofo camaronês Achille Mbembe, estabelecer uma chave de compreensão para a explicação do fato de que a estrutura operacional das instituições policiais são, até hoje, no Brasil, orientadas à aniquilação da população negra. Com efeito, a contemporaneidade tem demonstrado que são cada vez mais recorrentes os casos de atentados contra a vida de moradores das comunidades patrulhadas em operações comandadas pela Polícia ou pelo Exército. Os casos dos assassinatos de Marielle Franco, Evaldo Rosa dos Santos e Ágatha Félix foram apresentados como situações emblemáticas - dada a repercussão por eles alcançada em todo o país - desse cenário de produção deliberada de morte.

Na concepção do autor que deu sustentação à presente pesquisa, o estado de exceção e a relação de inimizade tornam-se a base normativa do direito de matar. Transpondo essa constatação para a realidade brasileira, não é difícil perceber a lógica factual da eleição da população negra pauperizada, que reside nas periferias das grandes cidades, para personificar a figura dos "inimigos", a partir de um racismo estrutural tributário do longo e violento período em que a escravidão grassou como sistema legítimo de ordenação social entre nós.

A partir das estatísticas reunidas e analisadas ao longo do texto, foi possível demonstrar, efetivamente, que os números de mortes de negros e brancos é distribuída de modo extremamente desigual no país - particularmente no que se refere às mortes produzidas na esteira das intervenções das instituições policiais do Estado brasileiro. Os homens negros, jovens e pobres são os alvos majoritariamente atingidos pelas armas de policiais em nosso solo.

Nisso reside a importante contribuição de Mbembe: dotar o estudo das políticas de morte levadas a cabo contra a população negra ao longo da história do Brasil de uma chave de compreensão - a necropolítica, que visa a demonstrar a relação entre biopoder, soberania e estado de exceção com o estabelecimento de uma política da morte que perpassa pela eleição de um inimigo que, em tais circunstancias, se torna o alvo, independentemente de oferecer um perigo concreto àqueles que ocupam, dentro deste vasto "império colonial", espaços privilegiados de poder. 


\section{REFERÊNCIAS:}

AGAMBEN, Giorgio. Estado de exceção. São Paulo: Boitempo Editorial, 2004.

AGAMBEN, Giorgio. 0 que resta de Auschwitz: o arquivo e a testemunha (Homo Sacer III). Trad. Selvino J. Assmann. São Paulo: Boitempo, 2008.

AGAMBEN, Giorgio. Meios sem fim: notas sobre a biopolítica. Trad. Davi Pessoa. Belo Horizonte: Autêntica, 2015.

ALMEIDA, Silvio. O que é racismo estrutural? Belo Horizonte: Letramento, 2018.

ARENDT, Hannah. Eichmann em Jerusalém. Tradução de José Rubens Siqueira. São Paulo: Companhia das Letras, 1999.

ARENDT, Hannah. Origens do totalitarismo: antissemitismo, imperialismo, totalitarismo. Trad. Roberto Raposo. São Paulo: Companhia das Letras, 2012.

AYUB, João Paulo. Introdução à analítica do poder de Michel Foucault. São Paulo: Intermeios, 2014.

BARBON, Júlia. 'Calma, amor, é o Exército', disse ao ouvir tiros viúva de músico fuzilado no Rio. Folha de São Paulo, Rio de Janeiro, 21 maio 2019. Disponível em: <https://www1.folha.uol.com.br/cotidiano/2019/05/calma-amor-e-o-exercito-disse-ao-ouvirtiros-viuva-de-musico-fuzilado-no-rio.shtml>. Acesso em: 17 fev. 2020.

BATISTA, Nilo. Os sistemas penais brasileiros. In. ANDRADE, Vera Regina Pereira de (org.). Verso e reverso do controle penal: (des)aprisionando a sociedade da cultura punitiva. vol. 1. Florianópolis: Fundação Boiteaux, p. 147-158, 2002.

BETIM, Felipe. Ciclo de impunidade em operações policiais com mortes ronda o caso Ágatha. EI País Brasil, São Paulo, 10 out. 2019. Disponível em: < https://brasil.elpais.com/brasil/2019/10/03/politica/1570057066_395793.html>. Acesso em: 17 mar. 2020.

BUENO, Samira; MARQUES, David; PACHECO, Dennis; NASCIMENTO, Talita. Análise da letalidade policial no Brasil. In. FÓRUM BRASILEIRO DE SEGURANÇA PÚBLICA. Anuário Brasileiro de Segurança Pública, 2019, p. 58-65. Disponível em: <http://www.forumseguranca.org.br/wpcontent/uploads/2019/10/Anuario-2019-FINAL_21.10.19.pdf>. Acesso em: 26 mar. 2020.

CARLOS, Ana Fani Alessandri. O lugar no/do mundo. São Paulo: FFLCH, 2007.

CASTRO, Edgardo. Lecturas foucaulteanas. Una historia conceptual de la biopolítica. La Plata: Unipe Editorial Universitaria, 2011.

CHALHOUB, Sidney. Cidade febril: cortiços e epidemias na Corte Imperial. São Paulo: Companhia das Letras, 1996. 
COELHO, Luiz. Cabeça de porco. Revista Landa, vol. 3, n. 1, p. 174-194, 2014. Disponível em: <http://www.revistalanda.ufsc.br/PDFs/vol3n1/10.\%20CHAMADA.\%20Luiz\%20Coelho\%20\%20Cabe\%C3\%A7a\%20de\%20porco.pdf>. Acesso em: 26 mar. 2020.

COMISSÃO INTERAMERICANA DE DIREITOS HUMANOS (CIDH). Comunicado de Imprensa no 52/2018. Disponível em: <http://www.oas.org/pt/cidh/prensa/notas/2018/052.asp >. Acesso em: 17 mar. 2020.

FANON, Frantz. Os Condenados da Terra. Trad. José Laurênio de Mello. Rio de Janeiro: Civilização Brasileira, 1968.

FERNANDES, Florestan. A integração do negro na sociedade de classes. Vol. 1. São Paulo: Dominus; Edusp, 1965.

FLAUZINA, Ana Luiza Pinheiro. Corpo negro caído no chão: o sistema penal e projeto genocida do Estado brasileiro. Rio de Janeiro: Contraponto, 2008.

FOUCAULT, Michel. Vigiar e punir: nascimento da prisão. Tradução de Raquel Ramalhete. 38. ed. Petrópolis, Rio de Janeiro: Vozes, 2010.

FOUCAULT, Michel. Em defesa da sociedade: curso no Collège de France (1975-1976). 2. ed. São Paulo: WMF Martins Fontes, 2010.

FÓRUM BRASILEIRO DE SEGURANÇA PÚBLICA. Anuário Brasileiro de Segurança Pública, 2019. Disponível em: <http://www.forumseguranca.org.br/wp-content/uploads/2019/10/Anuario2019-FINAL_21.10.19.pdf>. Acesso em: 26 mar. 2020.

FÓRUM BRASILEIRO DE SEGURANÇA PÚBLICA. Índice de Vulnerabilidade Juvenil à Violência e Desigualdade Racial. São Paulo, 2017. Disponível em: < http://www.forumseguranca.org.br/wp-

content/uploads/2018/10/FBSP_Vulnerabilidade_Juveni_Violencia_Desigualdade_Racial_2017 _Relatório.pdf>. Acesso em: 26 mar. 2020.

FREYRE, Gilberto. Casa grande \& senzala: formação da família brasileira sob o regime da economia patriarcal. Edição crítica de Guillermo Giucci, Enrique Larreta, Edson Fonseca. Paris: Allca XX, 2002.

GARCIA, Rodolfo. Ensaio sobre a história política e administrativa do Brasil. Rio de Janeiro: José Olympio, 1956.

GRAHAM, Stephen. Cidades sitiadas: o novo urbanismo militar. Tradução de Alyne Azuma. São Paulo: Boitempo, 2016.

HOBSBAWM, Eric. Globalização, democracia e terrorismo. Tradução de José Viegas. São Paulo: Companhia das Letras, 2007.

IPEA - Instituto de Pesquisa Econômica Aplicada. ATLAS DA VIOLÊNCIA 2018. Disponível em: $<$ http://www.ipea.gov.br/portal/images/stories/PDFs/relatorio_institucional/180604_atlas_da _violencia_2018.pdf>. Acesso em: 28 fev. 2020. 
JANSEN, Roberta. 'Tudo indica que militares confundiram o carro da família com o de assaltantes', diz delegado. Estadão, São Paulo, 08 abr. 2019. Disponível em: $<$ https://brasil.estadao.com.br/noticias/geral,tudo-indica-que-militares-confundiram-o-carroda-familia-com-o-de-assaltantes-diz-delegado,70002783415>. Acesso em: 17 fev. 2010.

JUCÁ, Beatriz. Doze militares são denunciados por fuzilamento de músico e catador no Rio. EI País Brasil, São Paulo, 10 maio 2019. Disponível em: <https://brasil.elpais.com/brasil/2019/05/11/politica/1557530968_201479.html>. Acesso em: 17 fev. 2020.

IANNI, Octavio. Raças e classes sociais no Brasil. 2. ed. Rio de Janeiro: Civilização Brasileira, 1972.

MBEMBE, Achille. Necropolítica: biopoder, soberania, estado de exceção, política da morte. Trad. Renata Santini. São Paulo: n-1, 2018a.

MBEMBE, Achille. Crítica da razão negra. Trad. Sebastião Nascimento. São Paulo: n-1, 2018b.

METALHEAD, Black Mirror, quarta temporada, quinto episódio. Direção de David Slade. Roteiro de Charlie Brooker. Inglaterra: Netflix, 2017. Acesso em: 11 fev. 2020.

NAÇÕES UNIDAS BRASIL. No Rio, pesquisadores aponta, que herança da violência colonial contra os negros continua até hoje. 2018. Disponível em: <https://nacoesunidas.org/no-riopesquisadores-apontam-que-heranca-da-violencia-colonial-contra-os-negros-continua-atehoje/>. Acesso em: 21 fev. 2020.

ODILLA, Fernanda. Em posts e projetos de lei: pelo que lutava Marielle Franco, vereadora assassinada no Rio. BBC Brasil, 15 mar. 2018. Disponível em: <https://www.bbc.com/portuguese/brasil-43398816>. Acesso em: 17 mar. 2020.

PANDOLFO, Alexandre; LINCK, José Antônio. Exbicho, exbíos, exmundo: "Metalhead", Black Mirror. Revista de la Asociación Argentina de Estudios de Cine y Audiovisual. n. 18, p. 675-682, 2018.

PELBART, Peter Pál. Novos povos onde nem existem. Palestinos/Judeus/negros/ homens livres etc. Peter Pál Pelbart. YouTube: Laboratório de Sensibilidades. 23 jun. 2018. Disponível em: https://www.youtube.com/watch?v=Mt838EcjKEl\&t=632s. Acesso em: 11 fev. 2020.

PELBART, Peter Pál. Vida Capital: Ensaios de Biopolítica. São Paulo: Iluminuras, 2003.

PEREIRA, Elson Manoel. Há relação entre a violência no Brasil e o direito à cidade? In. CARVALHO, Claudio Oliveira de; GRASSI, Karine; GRAZIANO SOBRINHO, Sergio Francisco Carlos (orgs.). Vidas urbanas e a vida nas cidades: regramentos urbanos, ambientais, seletividade e violências. Caxias do Sul: Educs, 2018. 
PETRONE, Talíria. A licença para matar pobres e favelados é uma realidade que vem sendo consolidada pelos sucessivos governos, inclusive em nível nacional. Carta Capital, s. I., 10 jun. 2019. Disponível em: <https://www.cartacapital.com.br/justica/a-politica-da-morte-dewitzel/>. Acesso em: 18 fev. 2020.

RAMOS, Silvia (coord.). Intervenção federal: um modelo para não copiar. Rio de Janeiro, CESeC, fevereiro de 2019. Disponível em: https://www.ucamcesec.com.br/textodownload/intervencao-federal-um-modelo-para-naocopiar/. Acesso em: 16 fev. 2019.

REVEL, Judith. Dicionário Foucault. Trad. Anderson Alexandre da Silva. Rio de Janeiro: Forense Universitária, 2011.

RIBEIRO, Djamila. O que é lugar de fala? Belo Horizonte: Letramento, 2017.

SCHWARCZ, Lilia Moritz. Previsões são sempre traiçoeiras: João Baptista de Lacerda e seu Brasil branco. História, Ciências, Saúde - Manguinhos, Rio de Janeiro, v.18, n.1, jan.-mar. 2011, p. 225-242.

SCHWARCZ, Lilia Moritz. Sobre o autoritarismo brasileiro. São Paulo: Companhia das Letras, 2019.

SEYFERTH, Giralda. Colonização, imigração e a questão racial no Brasil. Revista USP, n. 52, 2002.

SILVA, Luiz Antonio Machado da; LEITE, Márcia Pereira. Violência, crime e polícia: o que os favelados dizem quando falam desses temas? Sociedade e Estado, Brasília, v. 22, n. 3, p. 545591, set./dez. 2007. Disponível em: http://www.scielo.br/pdf/se/v22n3/04.pdf. Acesso em: 19 maio 2019.

SOUZA, Jessé. A elite do atraso: da escravidão à Lava Jato. Rio de Janeiro: Leya, 2017.

SOUZA, Marcelo Lopes de. Desafio metropolitano. Rio de Janeiro: Bertrand Brasil, 2000.

TRIBUNAL manda soltar 9 militares que mataram músico e catador no Rio. El País, São Paulo, 24 maio 2020.2 Disponível: <https://brasil.elpais.com/brasil/2019/05/24/politica/1558649132_143547.html>. Acesso em: 17 fev. 2020.

VAZ, Lilian Fessler. Dos cortiços às favelas e aos edifícios de apartamentos - a modernização da moradia no Rio de Janeiro. Análise Social, vol. XXIX, n. 127, 1994, p. 581-597. Disponível em: $<$ http://analisesocial.ics.ul.pt/documentos/122337718716iYL2uw3Xe43QN7.pdf >. Acesso em: 26 mar. 2020.

VON ESCHWEGE, Wilhelm Ludwig von. Pluto Brasiliensis. Vol. 1. São Paulo: Companhia Editora Nacional, $1944 . \quad$ Disponível em: <https://bdor.sibi.ufrj.br/bitstream/doc/343/1/257\%20T1\%20PDF\%20-\%200CR\%20\%20RED.pdf>. Acesso em: 26 mar. 2020. 
WACQUANT, Loïc. "Uma cidade negra entre os brancos". Revisitando o gueto negro da América. Tradução de Taís Blauth. Política \& Sociedade: Revista de Sociologia e Política, vol. 3, n. 5, p. 263-278, 2004. Disponível em: <https://periodicos.ufsc.br/index.php/politica/article/view/1993/1742>. Acesso em: 27 mar. 2020.

WERMUTH, Maiquel Ângelo Dezordi. Biopolítica e polícia soberana: a sociedade escravocrata como chave de compreensão da violência e da seletividade punitiva no Brasil. Revista Direitos Fundamentais e Democracia, v. 23, n. 3, p. 284-309, set./dez. 2018. Disponível em:

$<$ https://revistaeletronicardfd.unibrasil.com.br/index.php/rdfd/article/view/1262/564. Acesso em: 26 mar. 2020.

Trabalho enviado em 01 de abril de 2020

Aceito em 04 de maio de 2020 